\title{
Phosphoglycerate Kinase 1 Deficiency
}

National Cancer Institute

\section{Source}

National Cancer Institute. Phosphoglycerate Kinase 1 Deficiency. NCI Thesaurus. Code C126738.

An X-linked recessive inherited disorder caused by mutations in the PGK1 gene. Clinical manifestations include hemolytic anemia, myopathy, and neurologic involvement. 